TABLE 10

Comparative Median Annual Incomes and Salary Rates by Year of Bachelor Graduation

\begin{tabular}{ccccc}
\hline $\begin{array}{c}\text { Year of Bachelor } \\
\text { Graduation }\end{array}$ & Forestry & Agriculture & Engineering & $\begin{array}{c}\text { Natural } \\
\text { Science }\end{array}$ \\
\hline & $\$$ & $\$$ & $\$$ & $\$$ \\
Before 1920 & 11,050 & - & 11,700 & 10,600 \\
$1920-1924$ & 10,800 & - & 11,400 & 11,700 \\
$1925-1929$ & 9,950 & 7,600 & 10,900 & 10,600 \\
$1930-1934$ & 11,200 & 7,600 & 11,300 & 10,200 \\
$1935-1939$ & 9,600 & 8,100 & 11,100 & 10,500 \\
$1940-1944$ & 8,600 & 7,400 & 10,000 & 9,500 \\
$1945-1949$ & 7,700 & 7,100 & 9,200 & 8,300 \\
$1950-1954$ & 6,800 & 6,600 & 8,200 & 7,400 \\
$1955-1959$ & NA & 5,400 & 6,300 & 5,700 \\
1955 & 6,350 & 6,000 & 7,200 & 6,600 \\
1956 & 5,800 & 5,700 & 6,700 & 6,300 \\
1957 & 5,450 & 5,400 & 6,500 & 5,700 \\
1958 & 5,250 & 5,100 & 5,900 & 5,400 \\
1959 & 4,700 & 4,900 & 5,500 & 5,200 \\
\hline
\end{tabular}

second year. If any members have comments, either pro or con, on this suggestion, please contact the Salary Survey Committee. It is hoped that the Quebec Corporation also finds this survey report useful and we will welcome their participation in future surveys.

NOTE TO MEMBERS: Regardless of when the next survey is carried out PLEASE READ THE QUESTIONNAIRE CAREFULLY; ANSWER ALL QUESTIONS; RETURN THE QUESTIONNAIRE PROMPTLY.

\title{
C.I.F. Has New Head Office
}

The 1959 Annual Meeting of the Board of Directors agreed that the present location was not suitable, and that the Executive Committee appoint a Special Committee to look into the matter of the desirability of a new location for Head office.

During the 1959 Annual Meeting the Executive Committee appointed this Special Committee: Chairman, Mr. W. A. E. Pepler (as a past C.I.F. President) and the following members-Dr. D. R. Redmond of Ottawa, and Messrs. M. B. Morison of Toronto, and T. G. Wright of Vancouver.

The Committee listed four major requirements for a Head Office:

(1) good mail service, (2) low cost of travel of the Secretary-Manager to main centers, (3) convenience to national contacts, and (4) low cost rental (including hent, electricity, cleaning, parking, etc.), and indicated the OttawaMontreal region as best for items (2) and (3).

We felt that a locality, not directly associated with any of the four existing Canadian Forestry Faculties, and with a congenial environment, such as provided by the Woodlot Management program of Macdonald Col- 
lege and the Morgan Arboretum of truly national interest, would be most desirable.

In October, 1960, Mr. H. J. Hodgins, President of the C.I.F., visited Macdonald College and the nearby Morgan Arboretum with a view to considering this as a possible site for the new Head Office.

In December of 1960, Mr. Lowell Besley, Vice-President of the C.I.F., called on Dr. F. Cyril James, Principal and Vice Chancellor of McGill, with respect to the possibility of the C.I.F. obtaining quarters at Macdonald College.

On May 6th, $1961 \mathrm{Mr}$. Besley and the writer had conversations at Macdonald College with Dr. Dion, the Vice-Principal, and completed the detailed arrangements. The following letter of June 22nd from Dr. Dion to our President, Mr. Hodgins, confirmed these arrangements.

"I am very pleased to be able to inform you that, as a result of the representations that you have made to us and to the Secretary of the Board of Governors, and because of the support that you have been given by Professor Jones in particular, the Board of Governors has granted your request in the following terms:

"That the Canadian Institute of Forestry be granted space, free of charge, at Macdonald College, equivalent to two small offices for three years from June 1, 1961- subject to review in 1964."

In accordance with this provision, then, it is perfectly appropriate for your Mr. Dosne to make any arrangements he sees fit to move into the temporary quarters that we have made available to him on Maple Avenue, on the understanding that on or before September 1st more permanent quarters will be made available.

We are very pleased at the outcome of these negotiations and hope that the association between the Canadian Institute of Forestry and Macdonald College will be a long and mutually profitable one."

This, I believe, completes the job of the Committee on relocation of the Head office.

\section{NEWS OF THE SECTIONS}

W. A. E. PePLeR, Chairman.

\section{Nova Scotia}

John C. Currie, formerly District Forester with the Department of Lands and Forests, Nova Scotia, joined Nova Scotia Pulp Limited as Assistant to the Chief Forester June 1, 1961. Mr. Currie is presently living in Baddeck, N.S. His successor as Provincial District Forester for Annapolis County is Martin D. Butler, who was transferred from the Truro office of the Department of Lands and Forests. Mr. Butler's address is now Middleton, N.S.

Other Nova Scotia Department of Lands and Forests personnel changes include the promotion of G. R. Maybee to Regional Forester for Central Nova Scotia. Keith McKay succeeds Mr. Maybee as District Forester for Colchester County. Ralph Hale, Ronald Day and G. T. Ernst have been appointed Foresters, Extension Division of the Department. Mr. Hale was formerly Dis- 